\title{
A Literature Review on Quality of Working Life: A Case of Healthcare Workers
}

\author{
Giang Thuy Phan, Trung Quang Vo* \\ Department of Pharmacy Administration, Faculty of Pharmacy, University of Medicine and Pharmacy, Ho Chi Minh City 700000, Vie tnam.
}

\section{ARTICLE INFO}

Article history:

Received on: 28/02/2016

Revised on: 09/04/2016

Accepted on: 12/05/2016

Available online: 28/07/2016

Key words:

Quality of working life,

QWL, health professional,

nurse, systematic review.

\begin{abstract}
Objectives: The purpose of the study was to explore the characteristic of Quality of Working Life (QWL) research studies related to healthcare sector. Methods: We systematically searched PubMed, Science Direct, and Cochrane Library databases till February 2015. We uses those search term that are 'health occupation', 'health personnel', 'medical staff', 'nurse health care manpower', 'health manpower', 'healthcare manpower', 'health professional', 'practitioner', 'quality of working life', 'quality of work life', 'QWL' and 'QoWL'. Results: A total of 56 articles researching QWL were identified, of which 16 papers met the inclusion criteria. In those papers, the first study of QWL was published in 1994. Asia, America, and Europe had published seven, six and four papers, respectively. The number of papers that focus on QWL of nurses ( $n=9,52.9 \%)$ was the most concerned sector. There are over 200 participants $(n=9,52.9 \%)$ in the major studies. The factors that affect QWL are job satisfaction, homework interface, working conditions, compensation, human relations, managementpersonnel relations and support. Conclusion: Nowadays, there are nine countries that focus on QWL of healthcare staffs by researching and assessing concerned factors to enhance worker's satisfaction and support workers to be better manager change and transition.
\end{abstract}

\section{INTRODUCTION}

In the trend of changes in a number of aspects from environment to technology as well as the rise of employee unions, employers are suggesting salary as compensation and also create specific benefits to form a quality working environment that will fascinate and keep the talented brains in whole fields. In the past, the concepts of the quality of work life were various by many researchers through all the dimensions of QWL. Despite of existing since 1960s, during the international labour relations conference in Rome, Hian and Einstein have indicated the original term "Quality of Work Life" (QWL) as first being introduced in 1972(Hian and Einstein, 1990). The definition of Quality of working life is as need satisfaction getting from an interaction of employees' basic needs such as

\footnotetext{
* Corresponding Author

Trung Quang Vo, Department of Pharmacy Administration, Faculty of Pharmacy, University of Medicine and Pharmacy, Ho Chi Minh City 700000, Vietnam. Email: voquangtrungdk@gmail.com
}

survival and self-actualization needs and others correlated resources of organizations for meeting them (Efraty and Sirgy, 1990). QWL, in healthcare organizations, has been explicated as a compound of advantages and disadvantages in the work surrounding(Boonrod, 2009).

After a QWL program for work reforms was launched by United Auto Workers and General Motors Company in the United States of America to make jobs more satisfied, QWL got a number of concerns. QWL has been a multi-dimensional concept and it might not be eternal or universal. Individual has different needs linking to their jobs; the level their QWL is proved by whether those needs are being achieved. While some people could be satisfied with a simple minimum salary job that afford to pay the bills, others would search for such a position to be highly displeasing such a job to be so tedious or request too much physical labour(Jain and Thomas). Walton attributes the evolution of QWL to variable periods in history. Followed by the unionization change in the 1930's and 1940's, legislation enacted in early $20^{\text {th }}$ century that protected workers from incidents and eliminated job conditions were the initial stages (Walton, 1973). 
The emphasis was given on following factors, including working condition, job security, work place and economic gains, positive relationship between morale and productivity, equal employment opportunity, human needs and expectations, and relationship between motivation and leadership(Venkata Subrahmanyam C.V., 2013). In the health care system, the pressure to offer more effective service using the equivalent or cutoff resources is going to continue for the foreseeable future. Given transitions in third-party reimbursement increased contention from other healthcare infrastructures, especially set reimbursement amounts for a pointed diagnosis. Besides, healthcare organizations must enhance productivity for organizational existent to meet managed care requirements. However, if achieved at the expense of the quality of workers' working life, rise of productivity is likely to be fugitive (Brooks and Anderson, 2005)

QWL is considered a pivotal in decisions on apportion of the quality of life. A high QWL is an integral part of organizations to appeal and maintain employees. QWL is program-designated and comprehensive to enhance employee's satisfaction, support workplace learning and help workers better manager transition and alteration (Boonrod, 2009)In recent years, there is a numbers of QWL studies for many purposes (Mirkamali and Thani, 2011; Rethinam and Ismail, 2007; Rose et al, 2006). But up to until now, no study provides a comprehensive view of characteristics of QWL studies in healthcare. This study systematically reviews the studies of QWL related to healthcare worker explore factors affect QWL

\section{MATERIALS AND METHODS}

The electronic search was conducted based on PubMed, Science Direct and the Cochrane Library databases during the period of February 2015. We searched using the following search terms: 'health occupation', 'health personnel', 'medical staff', 'nurse health care manpower', 'health manpower', 'healthcare manpower', 'health professional', 'practitioner', 'quality of working life', 'quality of work life', 'QWL' and 'QoWL'. To get more eligible articles, we scanned the reference lists of the papers we selected to assess. From each study, we extracted year published and conducted, countries investigated, instruments used to assess QWL, sector, design of research assessed in the study, sample analysed in each study, period of time conducting, factors of assessment, results of article with related to methodological quality or factors of QWL. As our searched studies had a diversity of designs - those are quasi-experimental study, two-wave survey study, descriptive study. There are some limited descriptions of methods, so we cannot assess their methodological quality without available valid and reliable quality assessment instrument. This study sets out to identify and includes all published articles that (i) research quality of work life (QWL) (ii) use specific instruments and scales to assess QWL (iii) object is people working in medical organizations. Studies were excluded if they did not present both sides: the quality of working life and health professional. Studies were also rejected if they were not used English, not in health sector and not have full text.

\section{RESULT}

The flow diagram describing the process of systematic review is provided (figure 1). The combined searches found 47 potential titles. Of these, we rejected 25 articles after reviewing title/abstract as well as 9 articles for duplication and not writing by English. Of the total 13 articles, we excluded 6 articles not have full text. Next, we looked for eligible papers in reference lists of remaining papers. Finally, there are 16 papers included in our report.

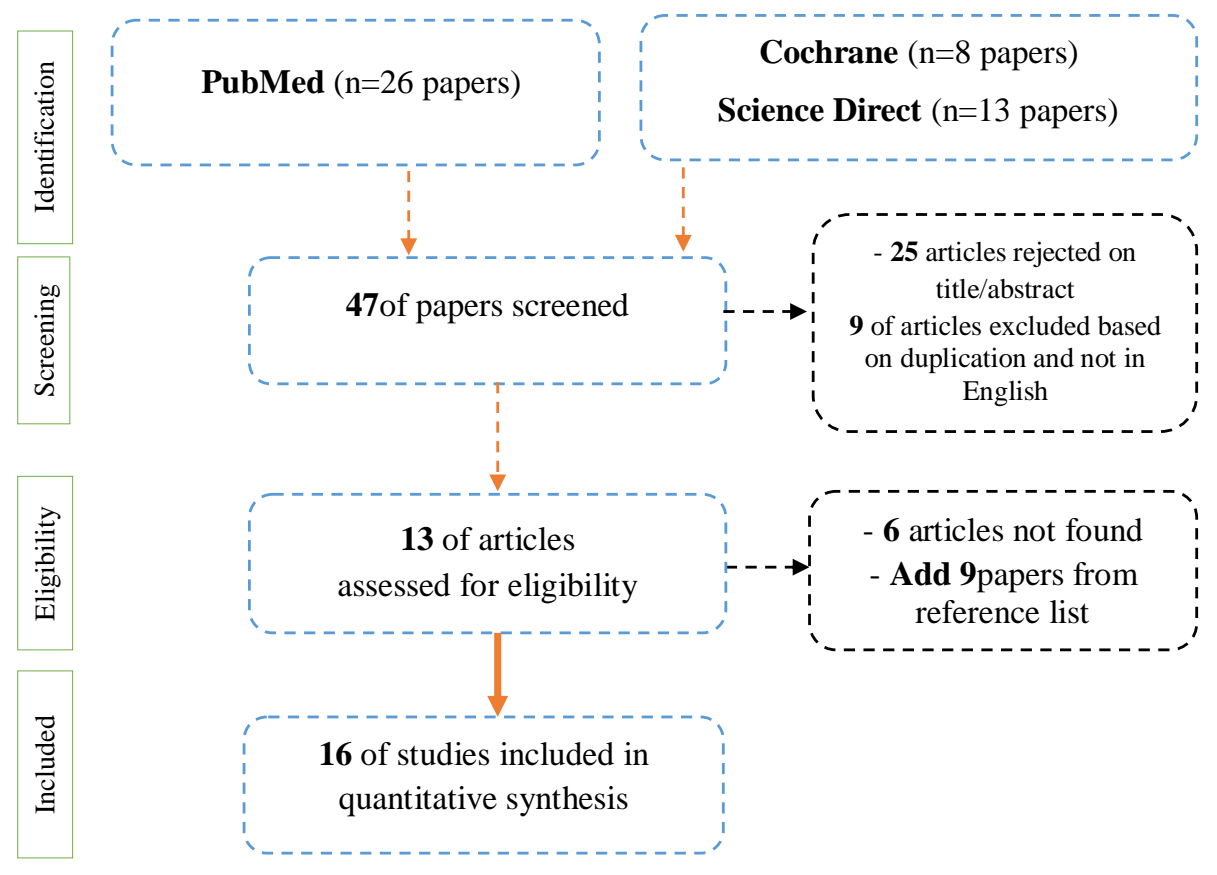

Fig. 1: Search flow for systematic review 


\section{General characteristics of publications}

In 16 articles we found 1 (table 1), the first study of QWL is published in 1994. Until 2002, another study had been conducted. From 2002 to 2009, there are one or two papers focusing on QWL every year. 2011 and 2012 are two remarkable years when having the most papers published- 4 papers each year. Besides, Asia had the most articles $(n=7,43.8 \%)$, the other articles were from America $(n=6,37.5 \%)$ and Europe $(n=3,18.8 \%)$. Especially, Canada and USA published three papers per country.

The second concerned factor is target employee of studies. Generally, studies classified three groups of respondents including doctors, nurses and staffs working in health care system. The most concerned health professional QWL was nurses $(n=8$, $50 \%)$, while physicians had the least concern $(n=3,18.8 \%)$. The others researched QWL of healthcare staffs $(n=5,31.3 \%)$. In the term of applied method, most of papers designed in descriptive research $(n=9,56.3 \%)$. Descriptive study measures the illness or conditions and adequate factors at a specific point in time for a chosen population. Descriptive studies can involve a one-time interaction with groups of people (cross-sectional study) or a study might follow individuals over time (longitudinal study). Those in which the researcher interacts with the participant, may involve surveys or interviews to collect the necessary information. The others are consisted of one quasi-experimental study, 2 two-wave studies and one paper did not mention its design.

As for sample of research, this study split them into three intervals to get the overview about the range of sample used. Most of studies $(n=11,68.8 \%)$ are conducted on the large sample, over 200 , the others were under 200 participants $(n=5,31.2 \%)$. There are a number of publications mentioning that authors use Likert scale for questionnaire. The number of articles using 5-point scale to score each item of dimensions or sub-dimensions including management-personnel relations and support, work aspects, job promotion, salary and rewards, and autonomy and so on was the most concerned $(n=8,50 \%)$.

Moreover, those papers use one or two software to analysis surveys. Most of them use SPSS, especially SPSS version $11(n=5,31.3 \%)$. Furthermore, most of papers $(n=11,68.8 \%)$ did not mention how long the research lasted. The other studies included four articles conducting within 3 months and two articles within 1 month. The period of time was difference depending on characteristic of study.

\section{Factors related to $\mathrm{QWL}$}

Studies are not only about QWL but also other factors relating to the work of medical staffs. Some factors which appeared in many studies are job satisfaction, homework interface, working conditions, compensation, human relations, managementpersonnel relations and support. Some papers focused on factors that related to only QWL(Cole et al, 2005; Hosseinabadi et al, 2012; Hsu and Kernohan, 2006). There is one study just listed questionnaire without mentioning specific dimension or factor (Beasley et al, 2004). Three articles restricted research in four factors: Work life/home life, work design, work context and work world(Almalki et al, 2012), Work life/home life, work design, work context and work world (Almalki et al, 2012), Hospital performance: rationale, open systems, internal process, human relations (Minvielle et al, 2008). Those gave accurately assessment and easy control. Some articles were highlighted with the factors more than other studies (Boonrod, 2009; Hornung et al, 2011; Krueger et al, 2002).

On the other hand, the results of those papers focused on: the mutual influence of factors (An et al, 2011; Hornung et al, 2011); the level of employee satisfaction with the given elements (Almalki et al, 2012; Beasley et al, 2005; Beasley et al, 2004; Minvielle et al, 2008; Nayeri et al, 2011); the differences between the study groups (Hosseinabadi et al, 2012; Sale and Smoke, 2007), the factors that impact on the QWL (Almalki et al, 2012; Boonrod, 2009; Cole et al, 2005; Hsu and Kernohan, 2006; Pronost et al, 2012; Smith et al, 1994) and important predictors of job satisfaction (Krueger et al, 2002).

We would clarify those main core of results at some important points. In the term of how the concerned factors were, we have two different issues. Those were the link of leadership dimension and idiosyncratic deals, the correlation between organizational culture, QWL and organizational effectiveness as well as the relation of QWL and turnover intention. Researches indicated some interesting results such as factor "Consideration" had compatible positive effects on idiosyncratic deals regarding both Professional development and Working time flexibility (Hornung et al, 2011) or organizational culture affected nurses' quality of work life (An et al, 2011). The second one is about how employees assessed their QWL as well as other dimensions based on some given factors.

Those factors are work life/home life, work design, work context and work world, hospital performance, work satisfaction, practice issues, outcomes, management-personnel relations and support, work aspects, job promotion, salary and rewards, and autonomy. The results are distinctive when researchers analysed different group of factors. Some level of the satisfaction could be listed. A paper concluded that the "shared values/ organizational climate" dimension was the most important factor (Minvielle et al, 2008). Another demonstrated the strong positive correlation between satisfaction with the heath care organizations and the physician's perceived ability to achieve professional goal, the perceived quality of care (Beasley et al, 2004).

We also should aggregate the typical opinions. Significant aspects nurses' QWL were human relationships, job value and self-actualization (Hsu and Kernohan, 2006). Moreover, the QWL was inversely related primarily to the lack of recognition, the lack of time, the poor consideration for patients and their families, the lack of training and the lack of collaboration(Pronost et al, 2012) and also positively related to job characteristics, organizational climate, organizational commitment and job satisfaction (Boonrod, 2009). Those are so helpful to give a holistic view so as to improving QWL. 
Table 1:Countries and published year of QWL publications

\begin{tabular}{llllllllll}
\hline $\begin{array}{l}\text { Continent } \\
\text { Country }\end{array}$ & Asia $(\mathbf{n}=\mathbf{7})$ & & & \multicolumn{2}{c}{ Europe $(\mathbf{n}=\mathbf{3})$} & \multicolumn{2}{l}{ America (n=6) } \\
\cline { 2 - 10 } & Korea & Taiwan & Iran & Saudi Arabia & Thailand & France & German & Canada & USA \\
\hline No of studies & 1 & 1 & 2 & 2 & 1 & 2 & 1 & 3 & 3 \\
Published year & 2011 & 2006 & 2011,2012 & 2012 & 2009 & 2008,2012 & 2011 & $2002,2005,2007$ & $1994,2004,2005$ \\
\hline
\end{tabular}

Table 2: Articles evaluated in this review $(\mathrm{n}=16)$.

\begin{tabular}{|c|c|c|c|c|c|c|c|c|c|}
\hline No & $\begin{array}{l}\text { Study, Year } \\
(\mathrm{N}=17)\end{array}$ & Country & Method & Scales & Software & Sector & Sample & $\begin{array}{l}\text { Period of } \\
\text { time }\end{array}$ & $\begin{array}{l}\text { Factors of } \\
\text { assessment }\end{array}$ \\
\hline 1 & $\begin{array}{l}\text { (Hosseinabadi } \\
\text { et al, 2012) }\end{array}$ & Iran & $\begin{array}{l}\text { Quasi- } \\
\text { experimental } \\
\text { study }\end{array}$ & $\begin{array}{l}\text { 5-point } \\
\text { Likert } \\
\text { scale }\end{array}$ & $\begin{array}{l}\text { SPSS } \\
\text { version } 13\end{array}$ & $\begin{array}{l}\text { Nursing, } \\
\text { emergency } \\
\text { medical } \\
\text { technician }\end{array}$ & 40 & 3 months & $\begin{array}{l}\text { Eight domains } \\
\text { of work-life } \\
\text { quality. }\end{array}$ \\
\hline
\end{tabular}

Result/Finding

After the intervention, there are significant differences between the quality circles and control groups in the scores linked to the domains of work and total space of life use and development of capacities and the total score of quality of work-life.

The actual range score $\begin{array}{ll}\text { Work } & \text { of the current study } \\ \text { was45 to } 218 \text { that is }\end{array}$ life/home life, lower than the (b) work design, (c) work context and (d) work world.

version 17 health care $508 \quad$ July 2009

average score of

Brooks' scale. This result indicated that the respondents were dissatisfied with their work life.

(Sale and Smoke, 2007)

Canada

QWL survey $\begin{aligned} & \text { 6-poin } \\ & \text { scale }\end{aligned}$

Staff in Year

Year $2(\mathrm{Y} 2)$ on personal $\mathrm{t}$, social support, work-

$\mathrm{n} / \mathrm{a}$
Job

satisfaction, emotional exhaustion, depersonalizati accomplishmen family conflict. .

The scores for the centre as a whole in $\mathrm{Y} 1$ and $\mathrm{Y} 2$ were moderate; however, there was considerable variation among employee groups for job satisfaction, burnout, social support, and work-family conflict. Work context variable makes the strongest unique contribution to explaining turnover intention. The link between turnover

Work life/home life, work design, work context and work world.

intention and each of the work life/home life and work world dimensions are mediated by the relationships between work design, work context and turnover intention.

$\begin{array}{ll}\text { Hospital } & \text { The "shared } \\ \text { performance: } & \text { values/organizational }\end{array}$ rationale, open climate" dimension systems, was the most internal process, human 
Table 3: Articles evaluated in this review ( $\mathrm{n}=16)$ (Continued)

\begin{tabular}{|c|c|c|c|c|c|c|c|c|}
\hline No & $\begin{array}{l}\text { Study, Year } \\
(\mathrm{N}=17)\end{array}$ & Country & Method & Scales & Software & Sector & Sample & $\begin{array}{l}\text { Period of } \\
\text { time }\end{array}$ \\
\hline 6 & $\begin{array}{l}\text { (Pronost et al, } \\
\text { 2012) }\end{array}$ & France & $\begin{array}{l}\text { Cross- } \\
\text { sectional } \\
\text { study }\end{array}$ & $\begin{array}{l}\text { 4- point } \\
\text { Likert } \\
\text { scale }\end{array}$ & $\begin{array}{l}\text { SAS version } \\
9.1\end{array}$ & $\begin{array}{l}\text { Caregiver } \\
\text { (nurses and } \\
\text { nurse aides) }\end{array}$ & 574 & $\mathrm{n} / \mathrm{a}$ \\
\hline
\end{tabular}

Factors of Result/Finding assessment

QWL, social The quality of work life support, was inversely related perceived primarily to the lack of stress, coping strategies.

recognition, the lack of time, the poor

consideration for patients and their families, the lack of training and the lack of collaboration.

\begin{tabular}{|c|c|c|c|c|c|c|c|c|c|}
\hline 7 & $\begin{array}{l}\text { (Hornung et al, } \\
\text { 2011) }\end{array}$ & German & $\begin{array}{l}\text { Two-wave } \\
\text { survey study }\end{array}$ & $\begin{array}{l}\text { 5-point } \\
\text { scale }\end{array}$ & $\begin{array}{l}\text { AMOS } \\
\text { version } 17.0\end{array}$ & $\begin{array}{l}\text { German } \\
\text { hospital } \\
\text { physicians }\end{array}$ & 301 & $\begin{array}{l}\text { The first } \\
\text { wave took } \\
\text { place in } \\
\text { spring } \\
2007\end{array}$ & $\begin{array}{l}\text { Leader } \\
\text { consideration } \\
\text { development } \\
\text { Idiosyncratic } \\
\text { deals, } \\
\text { flexibility } \\
\text { idiosyncratic } \\
\text { deals, work } \\
\text { engagement, } \\
\text { work-family } \\
\text { conflict. }\end{array}$ \\
\hline
\end{tabular}

Consideration had

consistent positive effects on idiosyncratic

deals regarding both

professional

development and working time flexibility.

These two types had

differential effects on

two indicators of the quality of working life.

Development related

positively to work engagement, flexibility related negatively to work-family conflict.

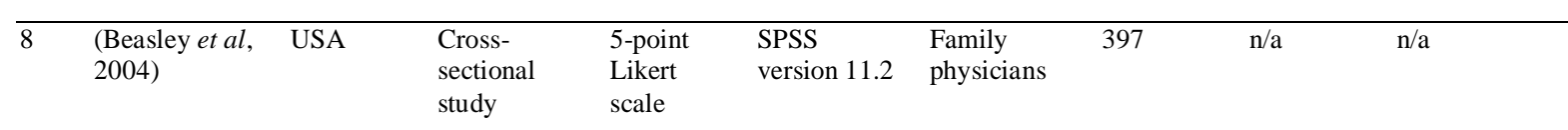

There is strong positive correlation between satisfaction with the $\mathrm{HCO}$ and the physician's perceived ability to achieve professional goal (0.54), the perceived quality of care $(0.27)$

\begin{tabular}{|c|c|c|c|c|c|c|c|c|c|c|}
\hline 9 & $\begin{array}{l}\text { (Beasley et al, } \\
\text { 2005) }\end{array}$ & USA & $\begin{array}{l}\text { Cross- } \\
\text { sectional } \\
\text { study }\end{array}$ & $\begin{array}{l}\text { 5-point } \\
\text { Likert } \\
\text { scale }\end{array}$ & $\begin{array}{l}\text { SPSS } \\
\text { version } 11.5\end{array}$ & $\begin{array}{l}\text { Family } \\
\text { Physicians }\end{array}$ & 628 & $\mathrm{n} / \mathrm{a}$ & $\begin{array}{l}\text { Work } \\
\text { satisfaction } \\
\text { Practice } \\
\text { issues } \\
\text { Outcomes }\end{array}$ & $\begin{array}{l}\text { The dependent variable } \\
\text { "satisfaction with } \\
\text { working relationships } \\
\text { among the physicians in } \\
\text { your work group" and } \\
\text { "ability to influence } \\
\text { management decisions } \\
\text { that affect your practice" } \\
\text { differed significantly } \\
\text { between independent } \\
\text { and HCO employed } \\
\text { family physicians (F= } \\
8.93, P=.003)\end{array}$ \\
\hline 10 & $\begin{array}{l}\text { (Krueger et al, } \\
2002 \text { ) }\end{array}$ & Canada & $\begin{array}{l}\text { Cross- } \\
\text { sectional } \\
\text { study }\end{array}$ & $\begin{array}{l}\text { 5-point } \\
\text { scale }\end{array}$ & $\begin{array}{l}\text { SPSS } \\
\text { version } \\
10.0 .5 \\
\text { Epi-Info } \\
\text { version } 6.04 \mathrm{a}\end{array}$ & $\begin{array}{l}\text { Full, part and } \\
\text { casual time } \\
\text { (non- } \\
\text { physician) } \\
\text { staff }\end{array}$ & 5,486 & $\mathrm{n} / \mathrm{a}$ & $\begin{array}{l}\text { Co-worker } \\
\text { and } \\
\text { supervisor } \\
\text { support; } \\
\text { organization } \\
\text { characteristic } \\
\text { s; patient/ } \\
\text { resident care; } \\
\text { salary and } \\
\text { benefits; } \\
\text { staff training } \\
\text { and } \\
\text { development }\end{array}$ & $\begin{array}{l}\text { The most important } \\
\text { predictors of job } \\
\text { satisfaction were: } \\
\text { Community hospital: } \\
\text { being satisfied with the } \\
\text { organization's } \\
\text { recognition of employee } \\
\text { contributions; } \\
\text { Community } \\
\text { hospital/long-term care } \\
\text { facility: good open } \\
\text { communication between } \\
\text { staff } \\
\text { Visiting nurse } \\
\text { organization. }\end{array}$ \\
\hline
\end{tabular}




\begin{tabular}{|c|c|c|c|c|c|c|c|c|c|c|}
\hline 11 & $\begin{array}{l}\text { (Boonrod } \\
\text {,2009) }\end{array}$ & Thailand & $\begin{array}{l}\text { Descripti } \\
\text { ve study }\end{array}$ & $\begin{array}{l}\text { 5-point } \\
\text { Likert scale }\end{array}$ & $\mathrm{n} / \mathrm{a}$ & $\begin{array}{l}\text { Professiona } \\
1 \text { nurses }\end{array}$ & 221 & $\begin{array}{l}\text { Septembe } \\
\text { r2007 }\end{array}$ & $\begin{array}{l}\text { Personal } \\
\text { factors, job } \\
\text { characteristics, } \\
\text { organizational } \\
\text { climate, job } \\
\text { satisfaction and } \\
\text { quality of } \\
\text { working life. }\end{array}$ & $\begin{array}{l}\text { The mean QWL was } \\
3.412 \pm 0.459 \text {, implying } \\
\text { that overall the level of } \\
\text { QWL is good. The } \\
\text { QWL is positively } \\
\text { related to job } \\
\text { characteristics, } \\
\text { organizational climate, } \\
\text { organizational } \\
\text { commitment and job } \\
\text { satisfaction. }\end{array}$ \\
\hline 12 & $\begin{array}{l}\text { (Hsu and } \\
\text { Kernohan } \\
\text {,2006) }\end{array}$ & Taiwan & $\begin{array}{l}\text { Descripti } \\
\text { ve study }\end{array}$ & $\mathrm{n} / \mathrm{a}$ & $\mathrm{n} / \mathrm{a}$ & $\begin{array}{l}\text { Hospital } \\
\text { nurses }\end{array}$ & 65 & $\mathrm{n} / \mathrm{a}$ & $\begin{array}{l}\text { Socio-economic } \\
\text { relevance, work } \\
\text { aspects } \\
\text { organizational } \\
\text { aspects, human } \\
\text { relation aspects } \\
\text { and self- } \\
\text { actualization. }\end{array}$ & $\begin{array}{l}\text { NQWL: results showed } \\
\text { that human } \\
\text { relationships, job value } \\
\text { and self-actualization } \\
\text { were significant } \\
\text { aspects of nurses' } \\
\text { QWL. }\end{array}$ \\
\hline 13 & $\begin{array}{l}\text { (Nayeri } \\
\text { et al, } \\
2011 \text { ) }\end{array}$ & Iran & $\begin{array}{l}\text { Cross- } \\
\text { sectional } \\
\text { study }\end{array}$ & $\begin{array}{l}\text { 5-point } \\
\text { Likert scale }\end{array}$ & $\mathrm{n} / \mathrm{a}$ & Nurses & 360 & $\mathrm{n} / \mathrm{a}$ & $\begin{array}{l}\text { Management- } \\
\text { personnel } \\
\text { relations and } \\
\text { support, work } \\
\text { aspects, job } \\
\text { promotion, } \\
\text { salary and } \\
\text { rewards, and } \\
\text { autonomy. }\end{array}$ & $\begin{array}{l}\text { Only } 3.6 \% \text { reported } \\
\text { their QWL to be high. } \\
\text { About one third of the } \\
\text { participants reported } \\
\text { their productivity as } \\
\text { moderate. All of } \\
\text { participants who had a } \\
\text { high or a very high } \\
\text { level of productivity } \\
\text { estimated their work } \\
\text { life quality as } \\
\text { desirable. }\end{array}$ \\
\hline 14 & $\begin{array}{l}\text { (An et al, } \\
2011 \text { ) }\end{array}$ & Korea & $\mathrm{n} / \mathrm{a}$ & $\begin{array}{l}\text { 5-point } \\
\text { scale, }\end{array}$ & $\begin{array}{l}\text { SAS } 8.2, \\
\text { AMOS } 5.0\end{array}$ & Nurses & 145 & $\begin{array}{l}\text { February } \\
2004\end{array}$ & $\begin{array}{l}\text { Organizational } \\
\text { culture } \\
\text { QWL, } \\
\text { organizational } \\
\text { effectiveness. }\end{array}$ & $\begin{array}{l}\text { A significant } \\
\text { difference was noted } \\
\text { with rationality culture } \\
\text { by education. Quality } \\
\text { of work life by age } \\
\text { showed a significant } \\
\text { difference in terms of } \\
\text { job }(\mathrm{F}=4.65, \mathrm{p}=.011) \\
\text { and compensation } \\
(\mathrm{F}=3.57, \mathrm{p}=0.030)\end{array}$ \\
\hline 15 & $\begin{array}{l}\text { (Cole } e t \\
a l, 2005)\end{array}$ & Canada & $\begin{array}{l}\text { Two- } \\
\text { phase } \\
\text { study }\end{array}$ & Interview & $\mathrm{n} / \mathrm{a}$ & $\begin{array}{l}\text { Canadian } \\
\text { HCOs }\end{array}$ & $\begin{array}{l}6 \text { public } \\
\text { HCOs } \\
58 \text { focus } \\
\text { groups }\end{array}$ & $\mathrm{n} / \mathrm{a}$ & QWL indicators & $\begin{array}{l}\text { QWL indicators were } \\
\text { relatively new to most } \\
\text { HCOs yet the data } \\
\text { managed by human } \\
\text { resource and } \\
\text { occupational health } \\
\text { and safety support } \\
\text { teams were highly } \\
\text { relevant to monitoring } \\
\text { of employee well- } \\
\text { being. }\end{array}$ \\
\hline 16 & $\begin{array}{l}\text { (Smith et } \\
\text { al }, 1994)\end{array}$ & $\begin{array}{l}\text { United } \\
\text { State of } \\
\text { America }\end{array}$ & $\begin{array}{l}\text { Case } \\
\text { study }\end{array}$ & $\begin{array}{l}\text { A } 5- \\
\text { interval } \\
\text { scale }\end{array}$ & $\mathrm{n} / \mathrm{a}$ & $\begin{array}{l}\text { Nurses, } \\
\text { homemaker } \\
\text { and staffs }\end{array}$ & 187 & $\mathrm{n} / \mathrm{a}$ & $\begin{array}{l}\text { QWL variables, } \\
\text { leadership } \\
\text { attributes }\end{array}$ & $\begin{array}{l}\text { Nurses express the } \\
\text { highest propensity to } \\
\text { remain. These job } \\
\text { attitudes have been } \\
\text { shown to be related to } \\
\text { higher job } \\
\text { performance. }\end{array}$ \\
\hline
\end{tabular}

\section{DISCUSSION}

Quality of work life has emerged as a popular concept. In the area of health care, the number of articles on QWL is increasing. It shows the proper attention of organizations on this important issue. QWL researches are conducted in many countries with different objects. Each study uses separate methodologies, tools to survey to assess the related factors to get high reliable result. According to our results, Idiosyncratic deals consisted of development as well as flexibility idiosyncratic deals. Leader consideration positively effects on idiosyncratic deals related to both items Professional development and Working time flexibility. Those two kinds had distinctive effects on two factors related to QWL(Hornung et al, 2011). Idiosyncratic deals mention to negotiated deflections from organizational practices related to standardized work and employment conditions. Furthermore, idiosyncratic deals have been implied to be reciprocally beneficial for employees and employers by enhancing the suitability between 
people and working and by that it provides conditions supporting the employee's well-being and sustained performance. Besides, that finding has been implied that idiosyncratic deals could play as a bond between employee-oriented leadership and QWL (Hornung et al, 2011). In addition, organizational culture had been significant related with QWL as well as organizational effectiveness. Organizational culture is a definition of a set of beliefs, values, behavioural patterns, and assumptions between members in organization (An et al, 2011). Chances for growth and improvement of employees can have an impact to organizational culture as well as organizational effectiveness. Furthermore, organizational culture directly and indirectly affect to QWL. So that the strategy to enhance organizational effectiveness is based on organizational culture. Since individual culture of organization is distinctive, study on organizational culture is mentioned crucial in organizational effectiveness study. According to results, intact organizational culture and QWL of nurses will definitely enhance organizational effectiveness.(An et al, 2011)

In additional, turnover intention was significantly correlation with QWLas results indicated that the respondents were dissatisfied with their work life, with almost $40 \%$ mentioning a turnover intention from their present primary health care (PHC) centres. Turnover of nurse has been a major issue for a number of health care organisations. Turnover of qualified nurses has unwanted results for both health organisations and the profession. Nurse turnover can have a negative affection on the capacity to meet patient needs and provide quality care. This result could be concerned to find out appropriate strategies to enhance QWL and to decline the turnover of PHC nurses. Sustaining a healthy work life for PHC nurses is essential to enhance their QWL, raise retention, improve performance and productivity and promote safe nursing care (Almalki et al., 2012).

In the studies of nurses' QWL, studies based on Brooks' research to assess QWL. The Brooks' survey of QWL of nurse(Brooks, 2001) has been appeared in other published studies in the USA and Iran with increasing global interest. Additionally, queries to applied Brooks' questionnaire have been come from scientists and graduate students in Greece, Estonia, Canada (Ontario, Quebec), India, Iran, Australia, Malaysia, Turkey, and Taiwan (Almalki et al, 2012)

Of 17 papers, there are six papers mentioning time they conducted study, mainly about step of survey or interview. The period of time is different among the studies. Time for conducting research is one of the most necessary items. It affects the accuracy of the research, the necessary funds, the number of respondents and research scope. In the case of tools used in the study, we assessed the scale used for the survey questions. The scales used in each article are different. In addition, there are some articles that uses many different scales, depending on the type of questions, concerned issues or respondents. Most of the studies used 5-point scale-point scale. There are some reasons indicating the suitability of this scale: It provides enough differentiation to allow respondents to tell you how they really feel, they would not be slowed down trying to choose between multiple ratings, the option in the middle will suit anyone who does not have an opinion. Therefore, results will be precise and reasonable. However, some opinions indicate disadvantages of that scale. For example, some people would think their distinctive capacity for perceived welfare to be limited to five levels of experience. Besides, there are some scale-construction factors that tend to reduce the effective choices. So expanding the number of scale points gives chances to improve questionnaire and the adequate scale format may be a 10-point, end-defined scale (Cummins and Gullone, 2000). In conclusion, the choice of researchers depends on concerned factors to use the most suitable scale for their study. Nowadays, there are different kinds of analysis tool in the world. In these articles, the tool used most is SPSS software, especially SPSS version 11. SPSS is a flexible and comprehensive statistical analysis and data management solution. They have large data sets, complex data interaction, accurate statistical analysis, strong field to graph and table scheduling, reporting and aggregating data, but weaker on some statistical procedures as reliable estimation method and absence of data analysis method according to the sample schema. So that, in other papers, researchers used different software being suitable for their result. However, six articles do not mention analysis software used. This is major deficiency because of making difficult for the readers in assessing the accuracy of the research as well as in the application of this research method.

This study has two important limitations. The main problem links to the quantity and the aim of the literature. Although we conducted a comprehensive search, we found only a limited group of publications with quantitative data. A second limitation is about summarizing the factors of QWL and result of them as well as how they affect positively or negatively to QWL. Since each paper is conducted with different aim and they did not just research QWL but other issues so there are many factors are mentioned and accessed.

\section{CONCLUSION}

QWL is concerned more and more in order to improve quality and productivity of working in organizations. Moreover, the study reveals some factors affecting the QWL such as job satisfaction, homework interface, working conditions, compensation, human relations, management-personnel relations and support to be better manager change and transition. They are so important to recognize and access the advantages and disadvantages of environmental working to get the appropriate solution addressing limiting factors and improve QWL.

\section{CONFLICT OF INTERESTS}

The authors have declared that no competing interests exist.

\section{REFERENCES}

Almalki MJ, Fitzgerald G, Clark M. Quality of work life among primary health care nurses in the Jazan region, Saudi Arabia: a crosssectional study. Hum Resour Health 2012; 10(1):30. 
Almalki MJ, FitzGerald G, Clark M. The relationship between quality of work life and turnover intention of primary health care nurses in Saudi Arabia. BMC Health Serv. Res. 2012; 12:314.

An JY, Yom YH, Ruggiero JS. Organizational culture, quality of work life, and organizational effectiveness in Korean university hospitals. J Transcult Nurs 2011; 22(1):22-30.

Beasley JW, Karsh BT, Hagenauer ME, Marchand L, Sainfort F. Quality of work life of independent vs employed family physicians in Wisconsin: A WReN study. Ann Fam Med 2005; 3(6):500-6.

Beasley JW, Karsh BT, Sainfort F, Hagenauer ME, Marchand L. Quality of work life of family physicians in Wisconsin's health care organizations: A WReN study. Wmj 2004; 103(7):51-5.

Boonrod W. Quality of working life: Perceptions of professional nurses at Phramongkutklao Hospital. J Med Assoc Thai 2009; 92 Suppl 1:S7-15.

Brooks BA. Development of an instrument to measure quality of nurses' worklife. 2001.

Brooks BA,Anderson MA. Defining quality of nursing work life. Nurs Econ 2005; 23(6):319-26, 279.

Cole DC, Robson LS, Lemieux-Charles L, McGuire W, Sicotte C, Champagne F. Quality of working life indicators in Canadian health care organizations: A tool for healthy, health care workplaces? Occup Med (Lond) 2005; 55(1):54-9.

Cummins RA,Gullone E. Why we should not use 5-point Likert scales: The case for subjective quality of life measurement. Proceedings, second international conference on quality of life in cities 2000:74-93.

Efraty D,Sirgy MJ. The effects of quality of working life (QWL) on employee behavioral responses. Social Indicators Research 1990; 22(1):31-47.

Hian CC,Einstein WO. Quality of work life (QWL): What can Unions Do? SAM Advanced Management Journal 1990; 55(2):17.

Hornung S, Glaser J, Rousseau DM, Angerer P, Weigl M. Employee-oriented leadership and quality of working life: mediating roles of idiosyncratic deals. Psychol Rep 2011; 108(1):59-74.

Hosseinabadi R, Karampourian A, Beiranvand S, Pournia Y. The effect of quality circles on job satisfaction and quality of work-life of staff in emergency medical services. International Emergency Nursing 2012; 21(4):264-70.

Hsu MY,Kernohan G. Dimensions of hospital nurses' quality of working life. J Adv Nurs 2006; 54(1):120-31.

Jain DY,Thomas R. Quality of work life: A comparative study of selected food units of chattral and charotar region of gujarat. IRMJCR.
Krueger P, Brazil K, Lohfeld L, Edward HG, Lewis D, Tjam E. Organization specific predictors of job satisfaction: findings from a Canadian multi-site quality of work life cross-sectional survey. BMC Health Serv. Res. 2002; 2(1):6.

Minvielle E, Sicotte C, Champagne F, Contandriopoulos AP, Jeantet M, Preaubert $\mathrm{N}$ et al. Hospital performance: Competing or shared values? Health Policy 2008; 87(1):8-19.

Mirkamali SM,Thani FN. A study on the quality of work life (QWL) among faculty members of University of Tehran (UT) and Sharif University of Technology (SUT). Procedia-Social and Behavioral Sciences 2011; 29:179-187.

Nayeri ND, Salehi T, Noghabi AA. Quality of work life and productivity among Iranian nurses. Contemp Nurse 2011; 39(1):106-18.

Pronost AM, Le Gouge A, Leboul D, Gardembas-Pain M, Berthou C, Giraudeau B et al. Relationships between the characteristics of oncohematology services providing palliative care and the sociodemographic characteristics of caregivers using health indicators: Social support, perceived stress, coping strategies, and quality of work life. Support Care Cancer 2012; 20(3):607-14.

Rethinam GS,Ismail M. Constructs of quality of work life: A perspective of information and technology professionals. European Journal of Social Sciences 2007; 7(1):58-70.

Rose RC, Beh L, Uli J, Idris K. An analysis of quality of work life (QWL) and career-related variables. American Journal of Applied Sciences 2006; 3(12):2151-2159.

Sale JE,Smoke M. Measuring quality of work-life: A participatory approach in a Canadian cancer center. J Cancer Educ 2007; 22(1):62-6.

Smith HL, Hood JN, Piland NF. Leadership and quality of working life in home health care. Home Health Care Serv Q 1994; 14(4):3-22.

Venkata Subrahmanyam C.V. SPM, Dr. K. Ravichandran. Quality of Work Life - The Need of the Hour. International Journal of Business and Management Invention 2013;2(11 (Version 1)):1-4.

Walton RE. Quality of Work Life: What is it? Sloan Management Review 1973; 15(1):11-21.

\section{How to cite this article:}

Phan GT, Vo TQ. A Literature Review on Quality of Working Life: A Case of Healthcare Workers. J App Pharm Sci, 2016; 6 (07): 193-200. 